\title{
IMPLEMENTASI KEBIJAKAN PENGELOLAAN BADAN USAHA MILIK DESA DALAM MENINGKATKAN PEREKONOMIAN DESA DI KECAMATAN JEPARA KABUPATEN JEPARA PROVINSI JAWA TENGAH
}

\author{
Oleh \\ Edo Pradipta Mahadika ${ }^{1}$, \\ Kusworo $^{2}$, Ondo Riyani ${ }^{3}$ \\ 1) Institut Pemerintahan Dalam Negeri \\ Program Magister Terapan Studi Pemerintahan Daerah Institut Pemerintahan Dalam Negeri \\ eddo.pradipta@yahoo.com \\ 2,3) Institut Pemerintahan Dalam Negeri
}

\begin{abstract}
"IMPLEMENTATION OF THE POLICY FOR THE MANAGEMENT OF VILLAGE OWNED BUSINESS ENTITIES IN IMPROVING THE VILLAGE ECONOMY IN JEPARA DISTRICT JEPARA REGENCY, WEST JAVA PROVINCE"
\end{abstract}

$T$ his research is motivated by the problem of the existence of Badan Usaha Milik Desa (BUMDes) in Jepara District, Jepara Regency which is considered not yet able to increase village income. The research method used in this research is a qualitative research method with a descriptive approach. Data obtained through data collection techniques: observation, interview and documentation. The analysis process uses SWOT analysis to identify the internal and external environment in BUMDes implementation, so that SO, WO, ST and WT are produced. The strategic issues obtained then use the Litmus Test to obtain strategic alternatives. The results show that the implementation of BUMDes management policies has not been able to improve the village economy in Jepara District, Jepara Regency due to communication clarity there is still a lack of synergy between the village government and BUMDes and the community and the lack of consistency in providing information about the management of BUMDes. Resource Implementing policies for the management of BUMDes in Jepara District have different capabilities and in terms of numbers are still lacking. Disposition/Attitude BUMDes management policy in Jepara District has been responded to by stakeholders implementers in the form of regulatory support, capital assistance and coaching as well as basic status to grow. Bureaucratic Structure the BUMDes organizational structure has been formed in each village and there is a division of tasks for the implementing managers with reference to the Jepara Regent regulation number 18 of the year. 2018. The most strategic step obtained is through optimizing the economic potential of the village, so that it is not only in the savings and loan business. BUMDes in Jepara District and need to conduct more incentive socialization so that village communities can know about the Badan Usaha Milik Desa program. The community in Jepara District must have an attitude of openness to the existence of Village Owned Enterprise activity programs in Jepara District.

Keywords: BUMDes; implementation; policy; village economy. 


\begin{abstract}
AbSTRAK
$\mathrm{P}$ enelitian ini dilatarbelakangi permasalahan keberadaan Badan Usaha Milik Desa (BUMDes) di Kecamatan Jepara, Kabupaten Jepara yang dinilai belum mampu mendongkrak pendapatan desa. Metode penelitian yang digunakan dalam penelitian adalah metode penelitian kualitatif dengan pendekatan deskriptif. Data diperoleh melalui teknik pengumpulan data: observasi, wawancara dan dokumentasi. Proses analisis menggunakan analisis SWOT untuk mengidentifikasi lingkungan internal dan eksternal dalam Implementasi BUMDes, sehingga dihasilkan SO, WO, ST dan WT. isu strategis yang diperoleh selanjutnya menggunakan Litmus Test untuk memperoleh alternatif strategis.Hasil penelitian menunjukkan bahwa Implementasi kebijakan pengelolaan BUMDes belum mampu meningkatkan perekonomian desa di Kecamatan Jepara Kabupaten Jepara disebabkan kejelasan komunikasi masih kurang sinergi antara pemerintah desa dengan BUMDes dan masyarakat serta masih kurang konsistennya memberikan informasi tentang pengelolaan BUMDes. Sumber Daya kebijakan pelaksana pengelolaan BUMDes di Kecamatan Jepara memiliki kemampuan yang berbedabeda dan dari segi jumlahnya masih kurang. Disposisi/Sikap kebijakan pengelolaan BUMDes di Kecamatan Jepara telah direspons oleh stakeholders pelaksana berupa dukungan peraturan, bantuan modal dan pembinaan serta status dasar menjadi tumbuh. Struktur Birokrasi telah terbentuk struktur organisasi BUMDes di masing-masing desa serta adanya pembagian tugas para pelaksana pengelola dengan mengacu pada peraturan Bupati Jepara No. 18 Tahun 2018. Langkah paling strategis yang diperoleh adalah melalui optimalisasi potensi ekonomi desa, sehingga tidak hanya pada usaha simpan pinjam. BUMDes di Kecamatan Jepara dan perlu melakukan sosialisasi lebih insentif lagi agar masyarakat desa bisa mengetahui program Badan Usaha Milik Desa. Masyarakat di Kecamatan Jepara harus memiliki sikap keterbukaan terhadap adanya program kegiatan Badan Usaha Milik Desa yang ada di Kecamatan Jepara
\end{abstract}

Kata kunci: BUMDes; implementasi; kebijakan; perekonomian desa.

\section{PENDAHULUAN}

$\mathrm{I}$ ndonesia merupakan negara kesatuan ynag memiliki prinsip otonomi daerah yang luas. Hal ini dilatarbelakangi oleh kondisi geografis Indonesia yang terdiri dari wilayah kepulauan. Selain itu keanekaragaman adat dan istiadat dari setiap wilayah yang ada menjadikan Indonesia negara yang kaya akan keberagaman.

Indonesia memiliki kekayaan alam yang sangat besar sehingga berpotensi untuk meningkatkan perekonomian dengan sumber daya alam yang dimiliki dengan segala isinya, daratan dengan segala bentuknya, serta lautan dengan segala potensinya yang akan dimanfaatkan secara terus-menerus untuk kepentingan pembangunan dan kepentingan masyarakat. Potensi tersebut merupakan aset yang dapat dimanfaatkan secara optimal dan menyeluruh melalui sektor perekonomian.

Salah satu implementasi dari program Nawacita adalah pemerintah memberikan perhatian besar terhadap desa, sebagai bagian dari kesatuan wilayah yang terendah dengan membentuk kelembagaan Negara setingkat menteri yang mengurusi permasalahan desa, yaitu Kementerian Desa, Pembangunan Daerah Tertinggal dan Transmigrasi. Hadirnya Kementerian Desa, Pembangunan Daerah Tertinggal dan Transmigrasi dapat menjadi agen pelaksana Undang-Undang No. 6 Tahun 2014 tentang Desa, yang secara substantif diharapkan dapat membangun desa melalui pendekatan struktural maupun kultural. UndangUndang No. 6 Tahun 2014 tentang Desa memberikan semangat baru bagi desa untuk memprakarsai dirinya dengan melahirkan semangat "desa membangun", artinya desa ditempatkan sebagai tonggak awal 
keberhasilan pembangunan secara nasional. Sehingga penguatan desa tidak lepas dari kekuatan desa dalam penggalian potensi kearifan lokal dan semangat gotong-royong warganya.

Desa memiliki kondisi modal sosial masyarakat yang sangat kuat dan telah mengakar. Salah satu bentuk modal sosial yang dimaksud dapat digambarkan melalui beragamnya ikatan sosial dan solidaritas sosial yang kuat dimiliki masyarakat desa sebagai penyangga penting kegiatan pemerintahan, pembangunan, dan kemasyarakatan (Susilo, Budi, \& Komara, 2016).

Demokrasi ekonomi Indonesia saat ini diwujudkan dalam 3 (tiga) pelaku utama perekonomian, yaitu Badan Usaha Milik Negara/Badan Usaha Milik Daerah (BUMN/ BUMD), Koperasi dan Swasta. BUMD dimaksud adalah hingga ke level desa berupa Badan Usaha Milik Desa (BUMDes).
Badan Usaha Milik Desa merupakan Lembaga ekonomi yang modal usahanya dibangun berdasar inisiatif masyarakat. Namun tidak menutup kemungkinan untuk mengajukan pinjaman modal kepada pihak luar (pemerintah desa atau pihak lain) serta pihak ketiga jika dirasa perlu (Gesty, Prihatin, \& Soemarmi, 2016). Hingga Desember 2018 tercatat sebanyak $61 \%$ desa telah memiliki BUMDes, atau telah terbentuk sebanyak 45.549 unit BUMDes di Indonesia. Jumlah ini meningkat tajam dari tahun 2014 yang hanya memiliki 1.022 BUMDes (Kementerian Desa, 2019)

Shodiqurrosyad (2017) mengharapkan BUMDes dapat memenuhi kebutuhan pokok masyarakat setempat di samping menekan selisih dari harga jual dan harga beli oleh para tengkulak. Produsen diharapkan dapat menerima harga produksi yang layak atas usahnya, serta konsumen juga tidak menanggung harga beli yang mahal.

Tabel 1. Badan Usaha Milik Desa (BUMDes) di Kabupaten Jepara Tahun 2019

\begin{tabular}{clcccc}
\hline \multirow{2}{*}{ No. } & \multirow{2}{*}{ Kecamatan } & \multirow{2}{*}{\begin{tabular}{c} 
Jumlah \\
\cline { 3 - 5 }
\end{tabular}} & & \multicolumn{3}{c}{ Status } \\
\cline { 4 - 6 } 1 & Bangsri & 12 & - & 4 & 8 \\
2 & Batealit & 11 & - & 4 & 7 \\
3 & Donorojo & 8 & - & 3 & 5 \\
4 & Jepara & 4 & - & 1 & 3 \\
5 & Kalinyamatan & 12 & - & 4 & 8 \\
6 & Karimunjawa & 4 & - & 2 & 2 \\
7 & Kedung & 18 & - & 6 & 12 \\
8 & Keling & 12 & - & 3 & 9 \\
9 & Kembang & 11 & - & 4 & 7 \\
10 & Mayong & 18 & - & 8 & 10 \\
11 & Mlonggo & 8 & - & 2 & 6 \\
12 & Nalumsari & 15 & - & 6 & 9 \\
13 & Pakisaji & 8 & - & 2 & 6 \\
14 & Pecangaan & 12 & - & 4 & 8 \\
15 & Tahunan & 15 & 1 & 6 & 8 \\
16 & Welahan & 15 & - & 6 & 7 \\
\hline & Jumlah Total & $\mathbf{1 8 4}$ & $\mathbf{1}$ & $\mathbf{9 3}$ & $\mathbf{9 0}$ \\
\hline
\end{tabular}

Sumber: Dinas Sosial Pemberdayaan Masyarakat dan Desa Kabupaten Jepara Tahun 2020. 
Pemerintah Kabupaten Jepara telah mengeluarkan Peraturan Bupati Jepara No. 18 Tahun 2017 tentang Pedoman Pengelolaan Badan Usaha Milik Desa Bersama yang menjadi dasar pembentukan BUMDes sebagai pendorong percepatan pembangunan desa di Kabupaten Jepara. Hal ini sesuai dengan misinya "Mewujudkan Perekonomian Daerah yang Progresif dan Mandiri" dengan harapan menurunkan kesenjangan Indeks Pembangunan Manusia (IPM) antara daerah perkotaan dan desa.

Pada dasarnya semua desa di Kabupaten Jepara Provinsi Jawa Tengah sudah memiliki Badan Usaha Milik Desa. Keberhasilan pengelolaan BUMDes dipengaruhi kebijakan pemerintah desa dan kreativitas pengelola. Keberadaan BUMDes belum berjalan optimal di Kabupaten Jepara, Jawa Tengah. Badan usaha Milik desa belum mampu mendongkrak pendapatan desa. Sebagaimana yang diberitakan surat kabar elektronik medcom.id bahwa:

Keberadaan BUMDes di Kabupaten Jepara belum berjalan optimal. BUMDes belum mampu mendongkrak pendapatan desa. Kepala Desa Lebak Kecamatan Pakisaji, sejak BUMDes digulirkan pemerintah desa sudah menyertakan modal Rp100 juta. Namun, sampai saat ini hasilnya belum bisa maksimal. "Setahun paling hanya Rp2 juta ke desa," ujar Sodiq, Kamis, 12 Desember 2019. BUMDes Lebak saat ini bergerak di bidang simpan pinjam. Namun, jalannya usaha tersendat disebabkan putaran uang pinjaman tidak berjalan baik. "Pinjam saja tidak ada yang menyimpan dan tidak lancar," kata Sodiq. Terpisah, Kepala Desa Kunir

Tabel 2. Indikator Kinerja Daerah Urusan Pemberdayaan Masyarakat dan Desa Kabupaten Jepara Tahun 2017-2019

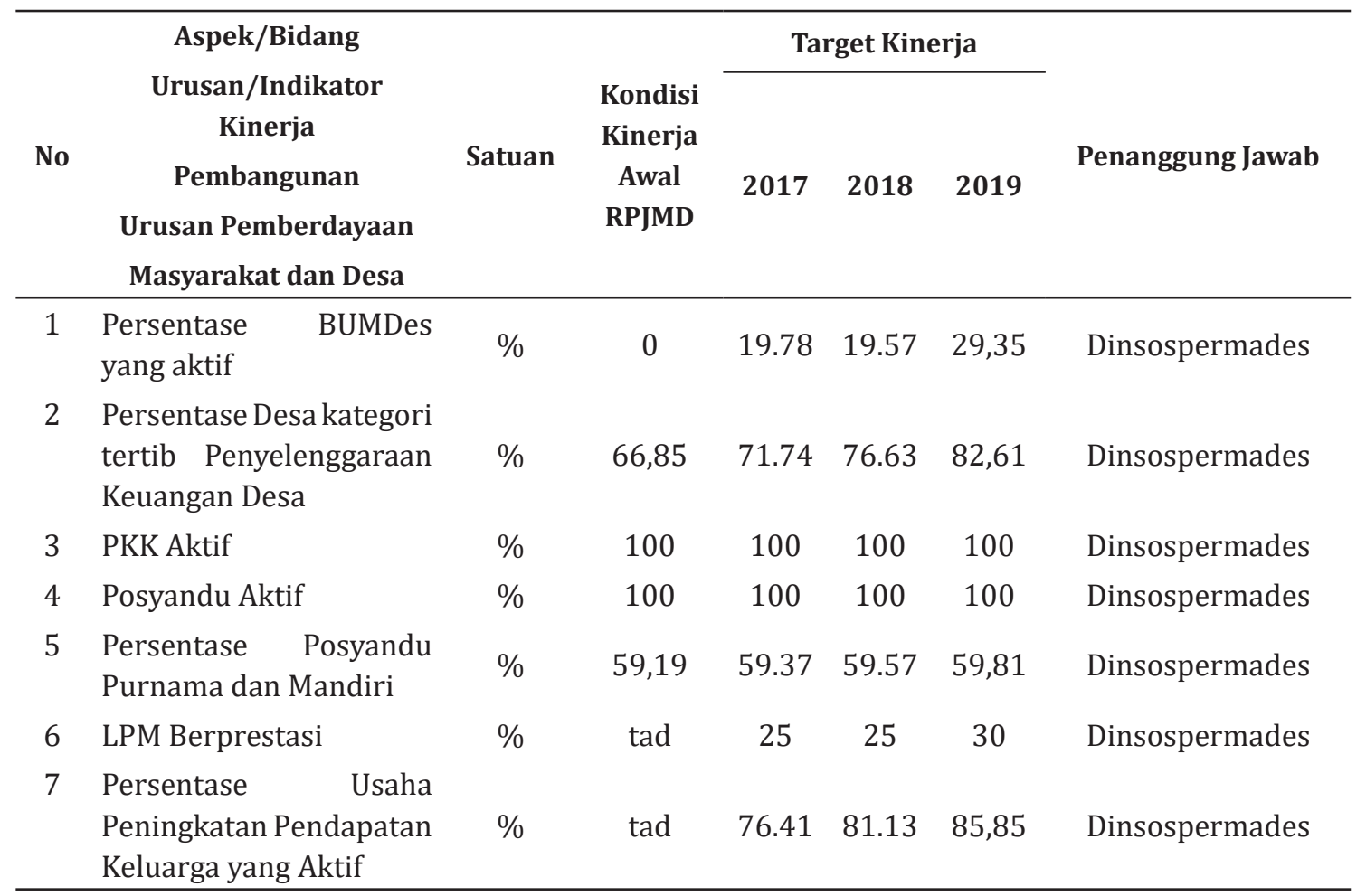

Sumber: Peraturan Daerah Kabupaten Jepara No. 2 Tahun 2018 tentang Rencana Pembangunan Jangka Menengah Daerah Kabupaten Jepara Tahun 2017-2022 
Kecamatan Keling, Sucipto, mengungkap BUMDes di wilayahnya bergerak di bidang peternakan sapi. Penyertaan modal desa sebesar Rp50 juta. "Sampai saat ini hasil ke desa sebagai pendapatan belum ada, masih di BUMDes. Sapi dikelola oleh kelompok masyarakat," kata Sucipto. Sucipto menambahkan BUMDes belum dapat menyumbang pendapatan desa. Dia mengungkap hasil dari BUMDes digunakan untuk mengembangkan usaha. Kepala Bidang Pemberdayaan Ekonomi Masyarakat pada Dinas Sosial Pemberdayaan Masyarakat Desa (Dinsospermades), Suharsana, mengatakan sebagian besar BUMDes bergerak di bidang simpan pinjam dan peternakan. Dari 184 desa di Kota Ukir, sebanyak 93 BUMDes status kelasnya dasar. "Artinya belum berkembang masih berjalan biasa-biasa saja" (Shani, 2019).

Tabel 2 di muka menjelaskan bahwa dari jumlah total BUMDes di Kabupaten Jepara sejumlah 184 Unit, persentase yang aktif pada 2019 sejumlah 29,35\% atau 54 unit. Keberadaan BUMDes belum dapat menyumbang pendapatan desa, terlebih mayoritas BUMDes statusnya belum berkembang sheingga otomatis belum maksimal dalam mengembangkan jenis usahanya. Dari 184 mayoritas berputar pada urusan simpan pinjam karena dianggap paling mudah dijalankan. pada tahap awal pendirian BUMDes, desa dimodali awal oleh pemerintah sebesar Rp 25 juta. Bantuan itu merupakan insentif untuk memacu pendirian badan usaha milik desa. Namun sekarang, dengan besarnya dana desa tidak ada lagi bantuan. Pemerintah desa diminta kreatif dalam pengembangan usaha. Beberapa desa, menurut Suharsana, telah berani mencoba jenis usaha lain, seperti pertokoan mebel. Pengembangan itu menurutnya bermula dari jasa simpan pinjam, yang terlebih dahulu dirintis pemerintah desa. Ada yang mulai mengembangkan menjadi pertokoan mebel, hal itu juga bermula dari usaha simpan pinjam. Nasabahnya berasal dari perajin, karena tidak bisa mengembalikan dalam bentuk uang, lalu dikembalikan dalam bentuk barang (Pranoto, 2017).

Pemerintah Kecamatan Jepara terus mendorong desa-desa yang ada di Kecamatan Jepara untuk selalu menggali potensi sumber daya alam yang ada di desa dalam rangka meningkatkan ekonomi desa. Perekonomian Desa yang ada di Kecamatan Jepara berdasarkan banyaknya industri kecil/kerajinan rumah tangga menurut jenisnya dapat dilihat pada tabel 3 .

BUMDes difungsikan sebagai tulang punggung pemerataan pertumbuhan ekonomi desa. Perekonomian di Kecamatan Jepara tidak terlepas dengan keberadaan BUMDes yang ada di Kecamatan Jepara yang

Tabel 3. Banyaknya Industri Kecil/Kerajinan Rumah Tangga Menurut Jenisnya di Kecamatan Jepara Tahun 2019

\begin{tabular}{llcccc}
\hline \multirow{2}{*}{ No } & Desa & $\begin{array}{c}\text { Industri Kecil } \\
\text { Makanan }\end{array}$ & Kulit & Kayu & Anyaman \\
\cline { 4 - 6 } & & 6 & - & 23 & - \\
2 & Bandengan & 8 & - & 15 & - \\
2 & Kedungcino & 7 & - & 8 & - \\
3 & Kuwasen & 8 & - & 6 & - \\
4 & Wonorejo & 21 & - & 104 & - \\
5 & Mulyoharjo & $\mathbf{5 0}$ & - & $\mathbf{1 5 6}$ & - \\
\hline
\end{tabular}

Sumber: Badan Pusat Statistik Kabupaten Jepara, 2020. 
menjadi suatu lembaga yang mewadahi sentra-sentra ekonomi di desa dengan semangat ekonomi kolektif (Agunggunanto, Arianti, \& Darwanto, 2016).

\section{METODE PENELITIAN}

Penelitian ini menggunakan metode deskriptif dengan pendekatan kualitatif dengan maksud memperoleh pemahaman terhadap fenomena dan ekstrapolasi pada situasi yang sama dengan peneliti sebagai instrument kunci dalam pengambilan sumber data, Teknik pengumpulan dan analisis data (Anggito \& Setiawan, 2018). Informan dalam penelitian ditentukan menggunakan teknik purposive sampling. Informan dipilih berdasarkan pertimbangan tertentu, yaitu dapat memberikan jawaban atas permasalahan dalam penelitian ini (Sugiyono, 2019).

Teknik pengumpulan data yang digunakan peneliti adalah melalui wawancara, dokumentasi dokumendokumen yang mendukung dalam menjawab permasalahan dan observasi. Dari data yang diperoleh kemudian dianalisis secara terus menerus hingga data jenuh, meliputi reduksi dalam penyajian data hingga penarikan simpulan. Adapun untuk menganalisis strategi yang tepat dalam implementasi kebijakan pengelolaan badan usaha milik desa dalam Meningkatkan Perekonomian Desa di Kecamatan Jepara Kabupaten Jepara Provinsi Jawa Tengah, maka penulis menggunakan analisis SWOT (strengths, weaknesses, opportunities, threats). Menurut Wasistiono dan Tahir (2007: 89-90) bahwa:

Analisis SWOT (strengths, weaknesses, opportunities, threats), merupakan analisis terhadap situasi dan kondisi yang berpengaruh, yang terdapat di lingkungan internal maupun lingkungan eksternal kebijakan. Analisis ini mencakup faktor-faktor yang menjadi kekuatan (strengths), Kelemahan (weaknesses), peluang (opportunities), dan ancaman (threats). Tujuan analisis ini adalah untuk mengetahui potensi issue-issue strategis yang kemungkinan dihadapi dalam implementasi kebijakan.

Melalui matriks di atas diperoleh isu-isu strategis yang teridentifikasi dan selanjutnya dievaluasi menjadi teman isu strategis. Penggunaan Litmus Test dalam mengembangkan strategi dari isu tersebut sebagaimana disarankan oleh Bryson (2007). Litmus Test terdiri dari pertanyaanpertanyaan yang harus dijawab dengan isu strategis yang terpilih. Jawaban yang diperoleh kemudian ditetapkan dengan skor rata-rata antara 1 (satu) sampai 3 (tiga), di mana semakin tinggi nilai skor suatu isu akan semakin strategis isu tersebut, sebaliknya semakin rendah nilai total skornya maka akan semakin tidak strategis. Isu yang kemudian dapat diartikan bahwa isu tersebut merupakan isu yang operasional di mana penyelesaiannya dapat dilakukan melalui kegiatan rutin saja.

\section{HASIL PENELITIAN DAN PEMBAHASAN}

\section{Implementasi Kebijakan Pengelolaan BUMDes dalam Meningkatkan Perekonomian Desa}

\section{- Komunikasi}

Syarat keberhasilan implementasi kebijakan menurut Edward III (Subarsono, 2016) adalah pelaksana kebijakan (implementor) tahu apa yang dikerjakan, apa tujuan dan sasaran kebijakan sehingga dapat di teruskan kepada kelompok sasaran. Jika tujuan dan sasaran tidak jelas akan menyebabkan resistensi dari kelompok sasaran kebijakan.

Pemerintah Kabupaten Jepara telah memberikan informasi jelas terkait pengelolaan BUMDes yang berisi peraturan tentang BUMDes yang disampaikan oleh Dinas Sosial Pemberdayaan Masyarakat Desa melalui camat di masing-masing wilayah 
bersama kepala desa. Hasil wawancara dengan Camat Jepara, Muchamad Syafi pada 10 Agustus 2020 pukul 13.00 WIB, diperoleh keterangan bahwa:

"Kejelasan komunikasi sudah berjalan dengan baik, hal ini ditandai dengan adanya sosialisasi payung hukum mengenai badan usaha milik desa. Selain itu juga terdapat pertukaran gagasan, pesan, ide, pengalaman maupun informasi mengenai programprogram unggulan dalam usaha untuk membangun dan meningkatkan perekonomian desa."

Kejelasan informasi dari Pemerintah Kabupaten Jepara melalui Dinas Pemberdayaan Masyarakat dan Desa Kabupaten Jepara tentang pengelolaan BUMDes sudah berjalan cukup baik, namun sayangnya belum menyentuh kepada pengelola BUMDes dan masyarakat. Minimnya informasi dan pendampingan dari perangkat desa kepada pengelola BUMDes menjadikan pengembangan usaha BUMDes terkendala dan belum signifikan memberikan hasil.

Kejelasan dalam berkomunikasi bukan hanya ditujukan kepada pelaksana kebijakan pengelolaan BUMDes atau implementor melainkan kepada masyarakat, hal tersebut juga sangat penting untuk masyarakat agar dapat memahami apa yang dimaksud pelaksana pengelola BUMDes dalam meningkatkan perekonomian desa.
Sebagaimana yang diungkapkan Masyarakat Desa Bandengan Siswoko, pada Kamis 13 Agustus 2020 pukul 09.00-10.00 WIB, bahwa:

"Kejelasan komunikasi dari pelaksana BUMDes di Kecamatan Jepara terhadap masyarakat masih kurang terlihat terutama mengenai usaha yang dikembangkan."

Berdasarkan pemaparan di atas kejelasan komunikasi kebijakan pengelolaan BUMDes dalam meningkatkan perekonomian desa di Kecamatan Jepara Kabupaten Jepara masih kurang sinergi antara pemerintah desa dengan BUMDes serta masyarakat.

\section{- Sumber Daya Manusia}

Sumber daya berdasarkan pendapat Edwards III dalam Subarsono (2016, p. 90) menjelaskan bahwa walaupun isi kebijakan sudah dikomunikasikan secara jelas dan konsisten, tetapi apabila implementor kekurangan sumber daya untuk melaksanakan implementasi maka tidak akan berjalan efektif. Kuantitas pengelola BUMDes di Kecamatan Jepara dapat dilihat pada Tabel 4.

Selain dari kuantitas, kualitas sumber daya merupakan hal yang penting dalam implementasi kebijakan. Sumber daya manusia yang bermutu dan profesional merupakan kunci dan modal utama yang dapat menentukan berhasil atau tidaknya sebuah implementasi kebijakan, karena

Tabel 4. Jumlah SDM Pengelola BUMDes Kecamatan Jepara Tahun 2019

\begin{tabular}{cllc}
\hline No & Desa & Nama BUMDes & Jumlah SDM (orang) \\
\hline 1 & Desa Mulyoharjo & Amanah Sejahtera & 4 \\
2 & Desa Kuwasen & Makustra & 6 \\
3 & Desa Bandengan & Setya Budi & 8 \\
4 & Desa Wonorejo & Ngudi Makmur & 3 \\
5 & Desa Kedungcino & Pandansari & 3 \\
\hline
\end{tabular}

Sumber: Dinas Sosial Pemberdayaan Masyarakat dan Desa Kabupaten Jepara Tahun 2020 
tanpa adanya sumber daya manusia sebagai penggerak, suatu pekerjaan tidak dapat dilaksanakan.

Berdasarkan hasil wawancara dengan Camat Jepara, Muchamad Syafi, pada Senin, 10 Agustus 2021 pukul 13.00-14.00 WIB, bahwa:

"Kemampuan sumber daya manusia pelaksana pengelola BUMDes sangat beraneka ragam, namun hal ini justru menjadi pemicu dan semangat bagi kami untuk terus belajar dan mengasah diri melalui pembinaan dan pelatihan untuk dapat berkontribusi meningkatkan perekonomian desa."

Hasil wawancara dengan Kepala Desa Bandengan, H. Sumadi, pada Selasa, 11 Agustus 2021 pukul 09.00-10.00 WIB bahwa:

"Kemampuan pengelola BUMDes harus dapat bermanfaat untuk berkembangnya BUMDes sehingga mampu menggerakkan perekonomian desa. Tidak masalah jika latar pendidikan pengelola berbeda, karena justru diharapkan mampu berbagi informasi yang beragam dalam menjalankan BUMDes".

Lebih lanjut Ketua Badan Permusyawaratan Desa Bandengan $\mathrm{H}$. Sukamto, pada Rabu, 12 Agustus 2021 pukul 09.00-10.00 WIB, mengungkapkan juga bahwa:

"Kemampuan sumber daya manusia pengelola BUMDes dapat disalurkan dengan baik untuk mewujudkan berkembangnya BUMDes ke arah yang lebih maju yang dapat menggerakkan perekonomian desa."

Berdasarkan pemaparan di atas kemampuan sumber daya manusia pelaksana pengelolaan BUMDes dalam meningkatkan perekonomian desa di Kecamatan Jepara Kabupaten Jepara memiliki kemampuan yang berbeda-beda serta dari segi jumlahnya masih sedikit.

\section{- Disposisi/Sikap}

Komitmen, kejujuran dan sifat demokratis merupakan karakteristik implementor sebagai bagian dari disposisi/ sikap menurut Edward III (Subarsono, 2016). Sikap akan menentukan bagaimana implementor menjalankan kebijakan. Respons pengelolaan BUMDes sudah diupayakan dengan adanya peraturan, bantuan modal dan pembinaan.

Berdasarkan hasil wawancara dengan Plt. Dinas Sosial Pemberdayaan Masyarakat dan Desa Kabupaten Jepara Suharsana, Senin, 10 Agustus 2020 pukul 09.00-10.00 WIB, mengungkapkan bahwa:

"Pengelola BUMDes sangat merespons terhadap pembinaan dan arahan kebijaksanaan yang dilaksanakan oleh pemerintah dalam pengelolaan BUMDes di desanya masing-masing".

Pemerintah desa yang ada di Kecamatan Jepara sudah menunjukkan respons yang baik terhadap pengembangan BUMDes yang ada di desanya. Pemerintah desa telah mendukung dengan keberadaannya BUMDes dan telah mengeluarkan antara lain: peraturan kepala desa, bantuan modal serta pembinaan. seperti yang diungkapkan oleh Sekretaris Desa Wonorejo Kunarti, Selasa, 11 Agustus 2020 pukul 13.00-14.00 WIB, bahwa:

"Pemerintah Desa sangat merespons dengan keberadaannya BUMDes karena ini akan menumbuhkembangkan perekonomian yang ada di desa. Bentuk respons/dukungan atas keberadaan BUMDes meliputi: keputusan kepala desa, bantuan modal serta pembinaan."

Respons dari pelaksana BUMDes disertai dengan tindakan pengembangan skala usaha. Adapun bentuk penilaian klasifikasi BUMDes di Kecamatan Jepara dapat dilihat pada Tabel 5. 
Tabel 5. Rekapitulasi Penilaian Klasifikasi Badan Usaha Milik Desa di Kecamatan Jepara Tahun 2019

\begin{tabular}{|c|c|c|c|c|c|c|}
\hline \multirow[b]{2}{*}{ No } & \multirow[b]{2}{*}{$\begin{array}{c}\text { Penilaian } \\
\text { Klasifikasi BUMDes }\end{array}$} & \multicolumn{5}{|c|}{ Nama BUMDes/Desa } \\
\hline & & $\begin{array}{c}\text { Amanah } \\
\text { Sejahtera } \\
\text { Desa } \\
\text { Mulyoharjo }\end{array}$ & $\begin{array}{l}\text { Makustra } \\
\text { Desa } \\
\text { Kuwasen }\end{array}$ & $\begin{array}{c}\text { Setya Budi } \\
\text { Desa } \\
\text { Bandengan }\end{array}$ & $\begin{array}{c}\text { Ngudi Makmur } \\
\text { Desa } \\
\text { Wonorejo }\end{array}$ & $\begin{array}{c}\text { Pandansari } \\
\text { Desa } \\
\text { Kedungcino }\end{array}$ \\
\hline 1 & Kelembagaan & 14,17 & 13,33 & 14,17 & 13,33 & 13,33 \\
\hline 2 & Aturan/Legalitas & 7,50 & 7,50 & 7,50 & 7,50 & 7,50 \\
\hline 3 & Usaha BUMDes & 12,50 & 12,50 & 12,50 & 12,50 & 12,50 \\
\hline 4 & $\begin{array}{l}\text { A d m i n is t r a s i, } \\
\text { Pelaporan dan Per- } \\
\text { tanggungjawaban }\end{array}$ & 5,83 & 5,83 & 5,83 & 5,83 & 5,83 \\
\hline 5 & $\begin{array}{l}\text { Permodalan dan } \\
\text { aset }\end{array}$ & 3,30 & 5,30 & 4,30 & 4,30 & 3,30 \\
\hline 6 & $\begin{array}{l}\text { Dampak BUMDes } \\
\text { terhadap } \\
\text { masyarakat }\end{array}$ & 10,00 & 10,00 & 10,00, & 10,00 & 10,00 \\
\hline 7 & $\begin{array}{l}\text { Klasifikasi tahun } \\
2019 / 2021\end{array}$ & $\begin{array}{l}\text { Tumbuh/ } \\
\text { Tumbuh }\end{array}$ & $\begin{array}{c}\text { Dasar/ } \\
\text { Tumbuh }\end{array}$ & $\begin{array}{c}\text { Dasar/ } \\
\text { Tumbuh }\end{array}$ & $\begin{array}{l}\text { Dasar/ } \\
\text { Tumbuh }\end{array}$ & $\begin{array}{c}\text { Dasar/ } \\
\text { Tumbuh }\end{array}$ \\
\hline
\end{tabular}

Sumber: Dinas Sosial Pemberdayaan Masyarakat dan Desa Kab. Jepara, 2020

Respons yang disertai tindakan oleh Pemerintah Kabupaten Jepara sampai kepada pengelola BUMDes menjadikan BUMDes di Kecamatan Jepara berstatus tumbuh, seluruhnya. Hal in diharapkan dapat mencapai tujuan kebijakan, yaitu meningkatkan perekonomian masyarakat desa di Kecamatan Jepara.

\section{- Struktur Birokrasi}

Pembentukan struktur organisasi pengelolaan Badan Usaha Milik Desa di Kabupaten Jepara mengacu kepada peraturan Bupati Jepara No. 18 Tahun 2018 tentang pengelolaan Badan Usaha Milik Desa dan Badan Usaha Milik Desa Bersama. Namun demikian dalam pelaksanaannya disesuaikan kembali dengan kebutuhan dari masing-masing BUMDes dengan tetap mengacu pada peraturan yang ada.

Hal tersebut ditegaskan oleh Camat Jepara, Muchamad Syafi, pada Senin, 10 Agustus 2020 pukul 13.00-14.00 WIB, bahwa:
"Untuk struktur Organisasi BUMDes berpedoman pada peraturan peraturan Bupati Jepara No. 18 Tahun 2017 tentang pengelolaan BUMDes dan BUMDes Bersama sesuai dengan kebutuhan masing-masing BUMDes."

Selanjutnya tugas para pelaksana BUMDes ditetapkan melalui keputusan kepala desa setempat. Lebih lanjut Plt. Dinas Sosial, Pemberdayaan Masyarakat dan Desa Kabupaten Jepara, Suharsana, pada Senin, 10 Agustus 2020 pukul 09.00-10.00 WIB, mengungkapkan bahwa:

"Pembagian tugas para pelaksana pengelola BUMDes sudah sesuai dengan tugas pokok dan fungsi ada di struktur organisasi BUMDes."

Hal yang sama diungkapkan juga oleh Camat Jepara, Muchamad Syafi, pada Senin, 10 Agustus 2020 pukul 13.00-14.00 WIB, bahwa:

"Pembagian tugas para pelaksana pengelola BUMDes sudah sesuai dengan fungsi dan tugas masing-masing di dalam struktur organisasi BUMDes." 


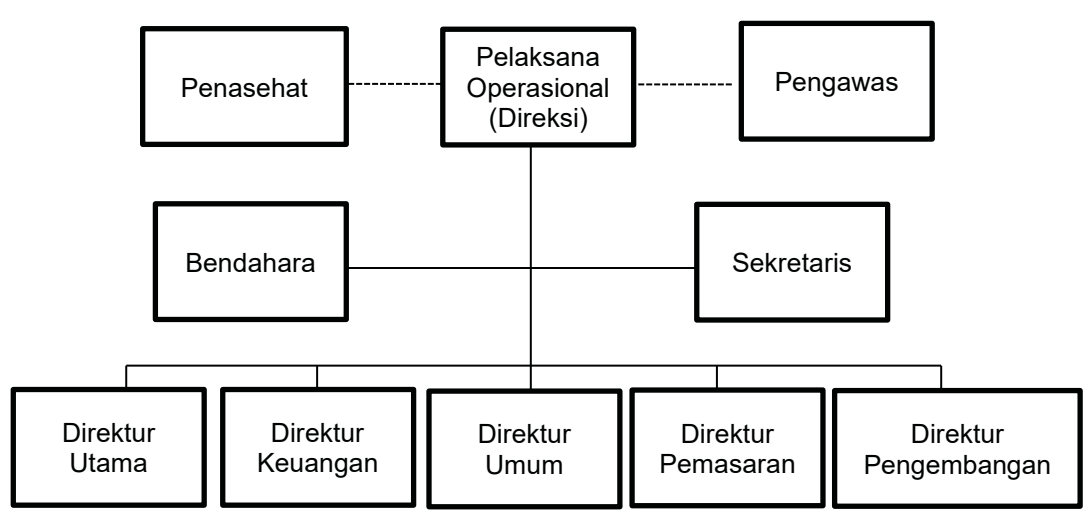

Gambar 1.

Struktur Pengelolaan Badan Usaha Milik Desa di Kabupaten Jepara berdasarkan Peraturan Bupati Jepara No. 18 Tahun 2018

Sumber: Dinas Sosial, Pemberdayaan Masyarakat dan Desa Kab. Jepara, 2020.

Faktor Pendukung Implementasi Kebijakan Pengelolaan Badan Usaha Milik Desa dalam Meningkatkan Perekonomian Desa

\section{- Kekuatan (S)}

Berdasarkan hasil wawancara dengan Plt. Dinas Sosial Pemberdayaan Masyarakat dan Desa Kabupaten Jepara Ir. Suharsana, M.Si. Senin, 10 Agustus 2020 pukul 09.0010.00 WIB dan Camat Jepara, Muchamad Syafi, pada Senin, 10 Agustus 2020 pukul 13.00-14.00 WIB, mengungkapkan bahwa faktor pendukung kekuatan implementasi kebijakan pengelolaan BUMDes dalam meningkatkan perekonomian desa di Kecamatan Jepara antara lain:

a. Sudah terbentuknya lembaga Badan Usaha Milik Desa

b. Mempunyai payung hukum

c. Adanya keuangan

d. Ketersediaan teknologi tepat guna

e. Potensi investasi yang menguntungkan

\section{- Peluang (0)}

Berdasarkan hasil wawancara dengan Plt. Dinas Sosial Pemberdayaan Masyarakat dan Desa Kabupaten Jepara, Suharsana, Senin, 10 Agustus 2020 pukul 09.00-10.00
WIB dan Camat Jepara, Muchamad Syafi, Senin, 10 Agustus 2020 pukul 13.0014.00 WIB mengungkapkan bahwa faktor pendukung peluang implementasi kebijakan pengelolaan BUMDes dalam meningkatkan perekonomian desa di Kecamatan Jepara antara lain:

a. Adanya dukungan dari pemerintah daerah dan desa

b. Adanya bantuan permodalan

c. Pemasaran bisnis basis on-line

d. Perluasan jaringan usaha

e. Menjalin Kerja sama

Faktor Penghambat Implementasi Kebijakan Pengelolaan Badan Usaha Milik Desa dalam Meningkatkan Perekonomian Desa

\section{- Kelemahan (W)}

Berdasarkan hasil wawancara dengan Plt. Dinas Sosial Pemberdayaan Masyarakat dan Desa Kabupaten Jepara Ir. Suharsana, M.Si. Senin, 10 Agustus 2020 pukul 09.0010.00 WIB dan Camat Jepara, Muchamad Syafi, pada Senin, 10 Agustus 2020 pukul 13.00-14.00 WIB mengungkapkan bahwa faktor penghambat kelemahan implementasi kebijakan pengelolaan BUMDes dalam 
Meningkatkan Perekonomian desa di Kecamatan Jepara antara lain:
a. Keterbatasan modal
b. Sumber daya alam yang masih kurang
c. Sumber daya pengelola BUMDes masih kurang
d. Kurangnya fasilitas penunjang
e. Kemampuan mengoperasikan teknologi yang kurang dikuasai

\section{- Ancaman (T)}

Berdasarkan hasil wawancara dengan Plt. Dinas Sosial Pemberdayaan Masyarakat dan Desa Kabupaten Jepara, Suharsana, pada Senin, 10 Agustus 2020 pukul 09.0010.00 WIB dan Camat Jepara, Muchamad Syafi, Senin, 10 Agustus 2020 pukul 13.0014.00 WIB mengungkapkan bahwa faktor penghambat ancaman implementasi kebijakan pengelolaan BUMDes dalam

Tabel 6. Matriks SWOT Faktor Pendukung dan Penghambat Implementasi Kebijakan Pengelolaan Badan Usaha Milik Desa dalam Meningkatkan Perekonomian desa di Kecamatan Jepara Kabupaten Jepara

Streghts (S) Weakness (W)

Faktor Internal

Faktor Eksternal Opportunities (0)
1. Sudah terbentuknya 1. Keterbatasan Modal lembaga Badan Usaha 2. Sumber daya alam yang masih Milik Desa kurang

2. Mempunyai payung 3. Sumber daya pengelolala hukum

3. Adanya keuangan BUMDes masih kurang

4. Ketersediaan teknologi tepat guna

5. Potensi investasi yang menguntungkan
4. Kurangnya fasilitas penunjang

5. Kemampuan mengoperasikan teknologi yang kurang dikuasai

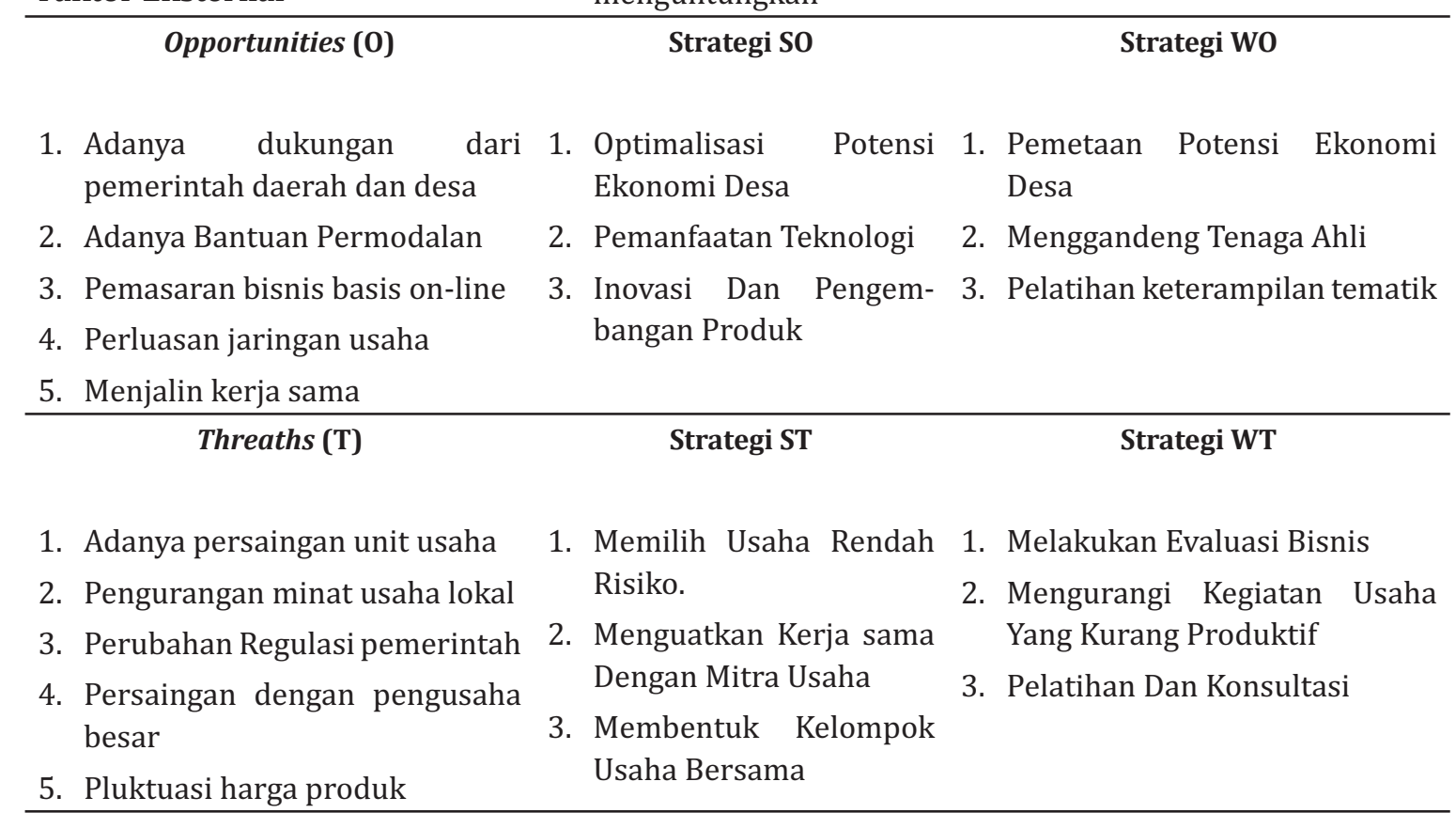

Sumber: Diolah peneliti, 2020 
meningkatkan perekonomian desa di Kecamatan Jepara antara lain:
a. Adanya persaingan unit usaha
b. Pengurangan minat usaha lokal
c. Perubahan regulasi pemerintah
d. Persaingan dengan pengusaha besar
e. Fluktuasi harga produk

Berdasarkan pemaparan di atas tentang faktor pendukung dan penghambat implementasi kebijakan pengelolaan BUMDes dalam meningkatkan perekonomian desa di Kecamatan Jepara Kabupaten Jepara Provinsi Jawa Tengah penulis tuangkan dalam bentuk matriks SWOT Tabel 6 di muka.

\section{Langkah Strategis yang Dapat Dilakukan oleh Pemerintah Daerah Kabupaten Jepara}

Melalui matriks di atas diperoleh isu-isu strategis yang dapat dilakukan Pemerintah Daerah Kabupaten Jepara guna mengatasi Faktor Penghambat Implementasi Kebijakan Pengelolaan BUMDes di Kecamatan Jepara Kabupaten Jepara sebagai berikut.
1. Optimalisasi Potensi Ekonomi Desa

2. Pemanfaatan Teknologi

3. Inovasi dan Pengem-bangan Produk

4. Memilih Usaha Rendah Risiko.

5. Menguatkan Kerja sama Dengan Mitra Usaha

6. Membentuk Kelompok Usaha Bersama

7. Melakukan Evaluasi Bisnis

8. Mengurangi Kegiatan Usaha Yang Kurang Produktif

9. Pelatihan dan Konsultasi

10. Pemetaan Potensi Ekonomi Desa

11. Menggandeng Tenaga Ahli

12. Pelatihan keterampilan tematik

Isu strategis tersebut selanjutnya dievaluasi menggunakan Litmus Test. Penggunaan Litmus Test dalam mengembangkan strategi dari isu tersebut. Pembobotan terhadap isu-isu strategis, diperoleh rumusan strategis yang merupakan prioritas utama langkah-langkah Strategis yang dapat dilakukan oleh Pemerintah Daerah Kabupaten Jepara guna mengatasi faktor-faktor penghambat, sebagai berikut.

Tabel 7. Hasil Test Litmus Implementasi Kebijakan Pengelolaan Badan Usaha Milik Desa dalam Meningkatkan Perekonomian desa di Kecamatan Jepara Kabupaten Jepara

\begin{tabular}{|c|c|c|c|c|c|c|c|c|c|c|c|c|c|}
\hline \multirow{3}{*}{ No } & \multirow{3}{*}{ Pertanyaan } & \multicolumn{12}{|c|}{ Strategi } \\
\hline & & \multicolumn{3}{|c|}{ S-O } & \multicolumn{3}{|c|}{ S-T } & \multicolumn{3}{|c|}{ W-T } & \multicolumn{3}{|c|}{ W-O } \\
\hline & & 1 & 2 & 3 & 4 & 5 & 6 & 7 & 8 & 9 & 10 & 11 & 12 \\
\hline \multirow[t]{2}{*}{1.} & $\begin{array}{l}\text { Kapan tantangan atau } \\
\text { peluang isu-isu strategis } \\
\text { optimalisasi potensi } \\
\text { ekonomi desa }\end{array}$ & 1 & 1 & 1 & 1 & 1 & 1 & 1 & 1 & 1 & 1 & 1 & 1 \\
\hline & di hadapan anda? & & & & & & & & & & & & \\
\hline 2. & $\begin{array}{lr}\text { Seberapa luas } & \text { isu } \\
\text { optimalisasi potensi } & \\
\text { ekonomi desa } & \text { akan } \\
\text { berpengaruh } & \text { pada } \\
\text { organisasi anda? } & \end{array}$ & 3 & 2,5 & 2,5 & 2,5 & 2,5 & 2,5 & 2,5 & 3 & 3 & 3 & 3 & 2,5 \\
\hline
\end{tabular}




\begin{tabular}{|c|c|c|c|c|c|c|c|c|c|c|c|c|c|}
\hline 3. & $\begin{array}{l}\text { Seberapa banyak risiko/ } \\
\text { peluang keuangan } \\
\text { organisasi anda? }\end{array}$ & 3 & 1,5 & 1,5 & 1,5 & 1,5 & 1,5 & 1,5 & 1,5 & 1,5 & 1,5 & 1,5 & 1,5 \\
\hline \multirow[t]{6}{*}{4.} & $\begin{array}{l}\text { Akankah strategi- } \\
\text { strategi bagi pemecahan } \\
\text { isu Optimalisasi potensi } \\
\text { ekonomi desa yang ada } \\
\text { oleh masyarakat akan } \\
\text { memerlukan: }\end{array}$ & & & & & & & & & & & & \\
\hline & 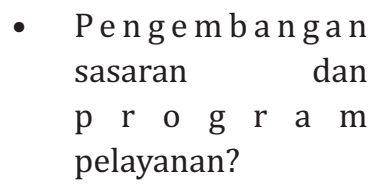 & 3 & 3 & 3 & 3 & 3 & 3 & 3 & 3 & 3 & 3 & 3 & 3 \\
\hline & 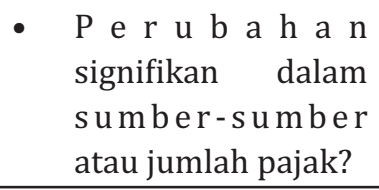 & 3 & 3 & 3 & 3 & 3 & 3 & 3 & 3 & 3 & 3 & 3 & 3 \\
\hline & 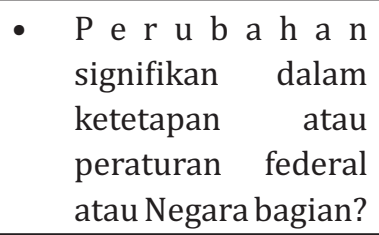 & 3 & 3 & 3 & 3 & 3 & 3 & 3 & 3 & 3 & 3 & 3 & 3 \\
\hline & $\begin{array}{l}\text { - Penambahan atau } \\
\text { modifikasi fasilitas } \\
\text { utama? }\end{array}$ & 3 & 3 & 3 & 3 & 3 & 3 & 3 & 3 & 3 & 3 & 3 & 3 \\
\hline & $\begin{array}{l}\text { - Penambahan staf } \\
\text { yang signifikan? }\end{array}$ & 3 & 3 & 3 & 3 & 3 & 3 & 3 & 3 & 3 & 3 & 3 & 3 \\
\hline
\end{tabular}

5. Bagaimana pendekatan $\begin{array}{llllllllllllll} & 3 & 3 & 3 & 3 & 3 & 3 & 3 & 3 & 3 & 3 & 3 & 3\end{array}$ yang terbaik bagi pemecahan masalah isu optimalisasi potensi ekonomi desa oleh masyarakat?

\begin{tabular}{|c|c|c|c|c|c|c|c|c|c|c|c|c|c|}
\hline 6. & $\begin{array}{l}\text { Tingkat manajemen } \\
\text { terendah manakah } \\
\text { yang dapat } \\
\text { menetapkan bagaimana } \\
\text { menanggulangi isu } \\
\text { optimalisasi potensi } \\
\text { ekonomi desa oleh } \\
\text { masyarakat? }\end{array}$ & 3 & 3 & 3 & 3 & 3 & 3 & 3 & 3 & 3 & 3 & 3 & 3 \\
\hline 7. & $\begin{array}{l}\text { Konsekuensi apakah } \\
\text { yang mungkin terjadi } \\
\text { bila isu optimalisasi } \\
\text { potensi ekonomi desa } \\
\text { oleh masyarakat tidak } \\
\text { diselesaikan? }\end{array}$ & 2,5 & 2,5 & 1,5 & 2,5 & 2,5 & 2,5 & 2,5 & 3 & 3 & 3 & 3 & 2,5 \\
\hline
\end{tabular}




\begin{tabular}{|c|c|c|c|c|c|c|c|c|c|c|c|c|c|}
\hline 8. & $\begin{array}{l}\text { Seberapa banyak } \\
\text { departemen lainnya } \\
\text { yang dipengaruhi oleh } \\
\text { isu optimalisasi potensi } \\
\text { ekonomi desa oleh } \\
\text { masyarakat ini dan } \\
\text { harus dilibatkan dalam } \\
\text { pemecahan? }\end{array}$ & 2,5 & 2,5 & 2,5 & 2,5 & 2,5 & 2,5 & 2,5 & 2,5 & 2,5 & 2,5 & 2,5 & 2,5 \\
\hline 9. & $\begin{array}{l}\begin{array}{l}\text { Bagaimana } \\
\text { atau }\end{array} \\
\begin{array}{r}\text { sensitifitas } \\
\text { optimalisasi }\end{array} \\
\text { ekonomi desa ini } \\
\text { terhadap nilai-nilai } \\
\text { sosial, politik, religious, } \\
\text { dan kultural komunitas? }\end{array}$ & 3 & 1 & 3 & 3 & 3 & 3 & 1 & 2,5 & 2,5 & 2,5 & 2,5 & 1 \\
\hline \multicolumn{2}{|c|}{ Total Skor } & 23 & 20 & 21 & 22 & 22 & 22 & 20 & 22,5 & 22,5 & 22,5 & 22,5 & 20 \\
\hline \multicolumn{2}{|c|}{ Rata-rata } & 2,6 & 2,2 & 2,3 & 2,4 & 2,4 & 2,4 & 2,2 & 2,5 & 2,5 & 2,5 & 2,5 & 2,2 \\
\hline
\end{tabular}

Sumber : Diolah oleh penulis, 2020

Perumusan isu-isu strategis yang diperoleh dari skor di atas kemudian ditetapkan berdasarkan tingkat kestrategisannya, sebagai berikut.

1. Optimalisasi potensi ekonomi desa dengan total skor rata-rata 2,6

2. Menggandeng tenaga ahli dengan total skor rata-rata 2,5

3. Pemetaan potensi ekonomi desa dengan total skor rata-rata 2,5

4. Pelatihan dan konsultasi dengan total skor rata-rata 2,5

5. Mengurangi kegiatan usaha yang kurang produktif dengan total skor rata-rata 2,5

6. Membentuk kelompok usaha bersama dengan total skor rata-rata 2,4

7. Menguatkan kerja sama dengan mitra usaha dengan total skor rata-rata 2,4

8. Memilih usaha rendah risiko dengan total skor rata-rata 2,4

9. Inovasi dan pengembangan produk dengan total skor rata-rata 2,3

10. Pemanfaatan teknologi dengan total skor rata-rata 2,2
11. Pelatihan keterampilan tematik dengan total skor rata-rata 2,2

12. Melakukan evaluasi bisnis dengan total skor rata-rata 2,2

Hasil penetapan kestrategisan di atas, diperoleh bahwa optimalisasi potensi desa merupakan isu dengan skor tertinggi. Meski dari ke semua dimensi yang ada memiliki rentang nilai yang tidak jauh berbeda satu dengan lainnya.

\section{SIMPULAN}

Berdasarkan hasil penelitian diperoleh simpulan sebagai berikut.

1. Implementasi kebijakan pengelolaan BUMDes dalam meningkatkan perekonomian desa di Kecamatan Jepara masih kurang baik. Aspek yang dinilai paling kurang dalam implementasi kebijakan ini adalah pada aspek komunikasi. Di mana pemerintah desa dan masyarakat masih belum bersinergi dalam menjalankan BUMDes sehingga hasilnya pun tentu belum optimal. Padahal jika dilihat dari aspek Sumber 
Daya, meskipun dengan pelaksana pengelola yang terbatas, namun mampu memberikan informasi yang mendukung melalui JDIH Kabupaten Jepara, Fasilitas pendukung pembinaan pelatihan dan sekolah BUMDes sudah disiapkan demi mendorong masyarakat untuk dapat aktif dalam menjalankan kebijakan tersebut. Dukungan dari stakeholder berupa regulasi pendukung, bantuan modal dan pembinaan telah diupayakan sehingga status BUMDes meningkat dari dasar menjadi tumbuh. Struktur Birokrasi di masing-masing desa telah terbentuk disertai pembagian tugas pelaksana yang mengacu Peraturan Bupati Jepara No. 18 Tahun 2018 tentang pengelolaan Badan Usaha Milik Desa dan Badan Usaha Milik Desa Bersama.

2. Faktor pendukung dan penghambat implementasi kebijakan pengelolaan BUMDes dalam meningkatkan perekonomian desa di Kecamatan Jepara Kabupaten Jepara Provinsi Jawa Tengah antara lain:

a. Faktor pendukung meliputi: Sudah terbentuknya lembaga BUMDes, mempunyai payung hukum, adanya keuangan, ketersediaan teknologi tepat guna, potensi investasi yang menguntungkan, adanya dukungan dari pemerintah daerah dan desa, adanya bantuan permodalan, pemasaran bisnis basis on-line, perluasan jaringan usaha dan menjalin kerja sama.

b. Faktor penghambat meliputi: Keterbatasan modal, Sumber daya alam yang masih kurang, Sumber daya pengelolala BUMDes masih kurang, Kurangnya fasilitas penunjang, Kemampuan mengoperasikan teknologi yang kurang dikuasai

3. Langkah strategis yang dapat dilakukan oleh Pemerintah Daerah
Kabupaten Jepara guna mengatasi faktor penghambat implementasi kebijakan pengelolaan BUMDes dalam meningkatkan perekonomian desa di Kecamatan Jepara Kabupaten Jepara Provinsi Jawa Tengah berdasarkan analisis SWOT melahirkan dua belas strategi dan yang menjadi prioritas utama adalah optimalisasi potensi ekonomi desa dengan nilai skor ratarata sebesar 2,6.

\section{DAFTAR RUJUKAN}

Agunggunanto, E. Y., Arianti, F., \& Darwanto, E. W. (2016). Pengembangan Desa Mandiri Melalui Pengelolaan Badan Usaha Milik Desa (BUMDes). Jurnal Dinamika Ekonomi \& Bisnis Vol. 13 No. 1, 67-81.

Anggito, A., \& Setiawan, J. (2018). Metodologi Penelitian Kualitatif. Sukabumi: CV. Jejak.

Bryson, M. J. (2007). Perencanaan Strategis Bagi Organisasi Sosial. Yogyakarta: Pustaka Pelajar.

Gesty, L. N., Prihatin, E. S., \& Soemarmi, A. (2016). Pelaksanaan Tugas Badan Usaha Milik Desa di Desa Jambu Kecamatan Mlonggo Kabupaten Jepara. Diponegoro Law Journal Vol. 5 No. 3, 1-18.

Kementerian Desa, P. D. (2019, April 26). Tercatat Sebanyak 61 Persen Desa Telah Memiliki BUMDes. Jakarta Pusat, DKI Jakarta, Indonesia.

Pranoto, P. (2017, Mei 22). BUMDes di Jepara Mayoritas Bergerak pada Usaha Simpan Pinjam. Diambil kembali dari murianews. com: https: //www.murianews. com/2017/05/22/116546/BUMDes-dijepara-mayoritas-bergerak-pada-usahasimpan-pinjam.html

Shani, R. (2019, Desember 12). BUMDes di Jepara Belum Mendongkrak Pendapatan Desa. Diambil kembali dari Medcom.id: https: //www.medcom.id/nasional/daerah/ akWVQGMb-BUMDes-di-jepara-belummendongkrak-pendapatan-desa 
Shodiqurrosyad, A. (2017, Mei 17). Urgensi BUMDes dalam Membangun Perekonomian Desa. Bojonegoro, Jawa Timur, Indonesia.

Subarsono, A. G. (2016). Analisis Kebijakan Publik. Yogyakarta: Pustaka Pelajar.
Sugiyono. (2019). Metode Penelitian Kuantitatif, Kualitatif dan R\&D. Bandung: Alfabeta.

Susilo, Budi, \& Komara, K. (2016). Membangun Gerakan Desa Wirausaha. Yogyakarta: Yayasan Penabulu. 